\title{
Factors Influencing the Intention to Obtain Accountant Certifications
}

\author{
AYU CHAIRINA LAKSMI* \\ INDAH SUCIATI \\ Universitas Islam Indonesia
}

\begin{abstract}
Professional accountant certification has many benefits for individual accountants as well as for the accounting profession in term of upscaling and increasing competitiveness. The purpose of this study is to examine the influence of attitude, subjective norms, and perceived behavior control on ACCA, CA and CPA professional accountant certifications and to understand students' intention to those certifications. The data were analyzed using multiple linear regression analysis. The results show that attitude and subjective norms have a positive and significant effect on students' intention to obtain the professional accountant certifications. The results also show that perceived behavior control does not have any negative and significant effect on students' intention, and the knowledge on those certifications does not have any positive and significant effect on students' intention. This study reveals the factors influencing students' intention to get professional accountant certifications.
\end{abstract}

Keywords: Intention, Certification, Professional Accountant

Intisari: Sertifikasi akuntan profesional memiliki banyak manfaat bagi akuntan individu maupun bagi profesi akuntansi dalam hal peningkatan dan peningkatan daya saing. Tujuan dari penelitian ini adalah untuk menguji pengaruh sikap, norma subyektif, dan kontrol perilaku yang dirasakan pada sertifikasi akuntan profesional ACCA, CA dan CPA dan untuk memahami niat siswa untuk sertifikasi tersebut. Data dianalisis menggunakan analisis regresi linier berganda. Hasil penelitian menunjukkan bahwa sikap dan norma subyektif memiliki pengaruh positif dan signifikan terhadap niat siswa untuk memperoleh sertifikasi akuntan profesional. Hasilnya juga menunjukkan bahwa kontrol perilaku yang dirasakan tidak memiliki pengaruh negatif dan signifikan terhadap niat siswa, dan pengetahuan pada sertifikasi tersebut tidak memiliki pengaruh positif dan signifikan terhadap niat siswa. Penelitian ini mengungkapkan faktor-faktor yang mempengaruhi niat siswa untuk mendapatkan sertifikasi akuntan profesional.

Kata Kunci: Niat, Sertifikasi, Akuntan Profesional 


\section{Introduction}

In 2014, 226.000 organizations in Indonesia required accountants (Anton, 2014), and the need for public accountant service for auditing firms was increasing (PPPK, 2016). Meanwhile, according to Center for Accountant and Appraiser Coaching (Pusat Pembinaan Akuntan dan Jasa Penilai, PPAJP), the Ministry of Finance recorded that there is less than 16,000 workforce available so that Indonesia lacks professional accountants (Anton, 2014). Indonesia's population is currently 237,641,326 (BPS, 2010). Despite its high population, Indonesia only has 1,186 Certified Professional Accountants (PPPK, 2016).

According to IAI (2014), Indonesia has 17,694 professional accountants, Malaysia 30,503, Philippines 22,072, Singapore 27,394, and Thailand 57,244. Indonesia has the lowest number of accountants than 4 ASEAN countries. According to Indarto et al. (2013), most of the auditors in Indonesia are 30 years old or above. Therefore, auditors working in Indonesia are elderly, and thus younger auditors are needed.

MEA has 4 characteristics: single market and production base, competitive economic region, equitable economic development, and fully integrated region in the global economy (The ASEAN Secretariat, 2015). It attempts to create a single market and production base through the more free flow of goods, services, investment, skilled workers, and capitals (The ASEAN Secretariat, 2015). Workers from various ASEAN countries will be free to choose to work outside their home countries. Skilled workers with professional accountant certification will be needed by almost every company. Since Indonesia lacks professional accountants, accountants from other ASEAN countries have a greater opportunity to work.

This topic needs to be investigated because many professional accountants are needed in Indonesia. It is caused by students' low interest in being professional accountants. To motivate students to get professional accountant certifications, lecturers and government have to understand the factors that can increase students' intention to get certified.

This study is aimed to provide empirical evidence on: (1) the influence of attitude toward professional accountant certifications on students' intention to get certified, (2) 
the influence of subjective norms in the certifications on students' intention to get certified, and (3) the influence of perceived behavioral control in the certifications and the comprehension of the certifications on students' intention to get certified.

\section{Theoretical Framework and Hypothesis Development}

\subsection{Theory of Planned Behavior}

Theory of Planned Behavior or TPB is the development of the Theory of Reasoned Action (TRA). TRA is based on the assumption that human beings usually behave consciously, considering the available information and implicitly and explicitly the implications or their actions (Jogiyanto, 2007). According to TRA, the intention is a function of two basic determinants, one of which is related to personal factors and the other to social influence.

According to Jogiyanto (2008), in TPB, the behavior of an individual is caused by behavioral intention, which is determined by three beliefs as follow:

a. Behavioral belief, which is the belief in the possibility of a behavior. It results in the attitude of liking or disliking a behavior.

b. Normative belief, which is the belief of a normative expectation from other people and motivation to agree with the expectation. It results in social pressure or subjective norms.

c. Control belief, which is the belief of factors facilitating or hindering the behaviors and the power of perception from those factors. It results in perceived behavioral control.

Attitude toward behavior, subjective norms, and perceived behavioral control simultaneously lead to behavioral intention, which then results in behavior. By identifying students' attitude toward accountant certifications, subjective norms, and perceived behavioral control, students' intention to get accountant certifications can be predicted.

\subsection{Intention}

Jogiyanto (2007) explained that an intention is the willingness to do something. According to Arisudana (2009), the intention is a component in an individual which 
refers to the willingness to do a behavior, while behavior is a real act from that willingness. Meanwhile, Sulistiani (2012) stated that an intention is closely related to motivation, the urge of an individual to consciously or unconsciously take action with a particular purpose; a good intention will encourage motivation to do something good.

According to Jogiyanto (2007), an intention changes as the time goes by, so a longer period means a greater chance of changing an intention. TPB explains that an intention may come from the beliefs of an individual. Greater behavioral belief, normative belief, and control belief result in a greater intention to do a certain behavior. The following factors influence an intention.

a. Attitude. According to Jogiyanto (2007), attitude is the evaluation of a belief or a positive or negative feeling in doing something. Meanwhile, Hidayat (2010) defined attitude as favorableness or unfavorableness toward an object. Based on a study conducted by Sumaryono (2016) the attitude toward Chartered Accountant (CA) has a positive and significant influence on students' intention to get CA certification.

b. Subjective norms. According to Fishbein and Ajzen (1975), Subjective norms are beliefs of an individual in the expectation of certain behavior from people around him/her. Based on Sumaryono's study (2016), subjective norms has a positive and significant influence on students' intention to get CA certification.

c. Perceived behavioral control. Perceived behavioral control is defined by Ajzen (1991, in Jogiyanto, 2007) as perceived ease or difficulty in doing a behavior. According to Ajzen (1991), more resources, opportunities, and beliefs owned by an individual result in fewer obstacles and a greater chance for a behavior to be done. Generally, the more attractive the attitude and subjective norms of behavior are, and the greater the perceived behavioral control is, the stronger the interest to do the considered behavior is (Jogiyanto, 2007). Meanwhile, Sumaryono (2016) stated that perceived behavioral control in CA has a positive and significant influence on students' intention to get CA certification.

d. Comprehension

According to Arikunto (2009) comprehension is the way of how an individual defends, differentiates, explains, expands, concludes, gives examples, rewrites, and estimates 
something. Comprehension enables an individual to make a conclusion or give an explanation on an object. This study focused on students' comprehension on the certifications of ACCA, CA, and CPA and Regulation of the Minister of Finance of the Republic of Indonesia Number 25/PMK.01/2014 on State-Registered Accountants and Law of the Republic of Indonesia Number 5 the Year 2011 Chapter III on the Licensing of the Public Accountant Article 6.

This study focused on attitude, subjective norms, and perceived behavioral control according to TPB and the level of students' comprehension on the certifications CA, ACCA dan CPA, which is assumed to influence students' intention to get those certifications. According to Sumaryono (2016), the level of comprehension shows how well an individual understands a concept or content of an object. Following the goals of Regulation of the Minister of Finance of the Republic of Indonesia Number 25/PMK.01/2014 on State-Registered Accountants to protect the public interest, guide accountants, and encourage the development of accountant profession in Indonesia to face the global challenge, students are expected to understand the regulation and get professional accountant certifications.

\subsection{Theoretical Framework and Hypotheses Development}

Figure 1.

Theoretical Framework of the Study

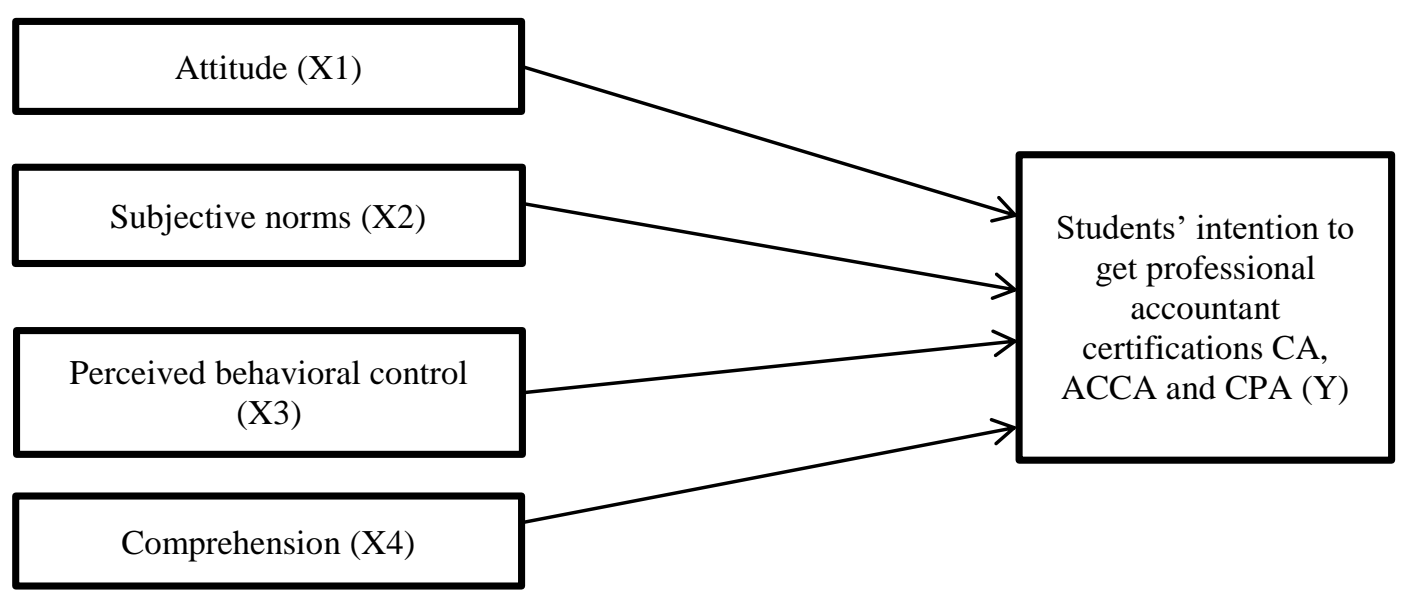


The theoretical framework of this study is presented in Figure 1. The independent variables were attitude, subjective norms, perceived behavioral control, and comprehension, while the dependent variable is the intention to get professional accountant certifications.

Based on the theoretical framework, the hypotheses were formulated as follow:

\subsubsection{The influence of attitude on students' intention to get professional accountant certifications}

According to Jogiyanto (2007), attitude is the evaluation of a belief or a positive or negative feeling in doing something. The evaluation of a belief for or against the behavior of a student in getting professional accountant certifications is the feeling related to the benefits of getting certified.

Sumaryono (2016) found a positive and significant relationship between students' attitude toward Chartered Accountant (CA) and their intention to get CA certification. Trikristriani (2014) found that students' attitude toward public accountants has a positive influence on their intention to be public accountants. Meanwhile, Solikhah (2014) found that the attitude toward Certified Public Accountant (CPA) and the law of CPA influences the intention to start a career as a CPA. Therefore, the hypothesis was formulated as follow:

H1. The attitude toward professional accountant certifications has a positive influence on students' intention to get the certifications.

\subsubsection{The influence of subjective norms on students' intention to get professional accountant certifications}

According to Jogiyanto (2007), subjective norms are perception or point of view of an individual on the beliefs of others which influences the intention to do or not to do a specific behavior. To get professional accountant certifications, students need advice from other people, which are called referents. Referents for students are usually teachers, parents, or friends who have got the certifications. 
Sumaryono (2016) found that there is a positive and significant relationship between subjective norms on CA and students' intention to get CA certification. Furthermore, Wardani (2016) found that subjective norms have a significant influence on the intention to get the certification. Subjective norms also have a positive influence on students' intention to be public accountants (Trikristriani, 2014). The same result applies to the relationship between subjective norms and the intention to be certified public accountants (Solikhah, 2014). Thus, the hypothesis was formulated as follow.

H2. Subjective norms on professional accountant certifications have a positive influence on students' intention to get the certifications.

2.3.3 The influence of perceived behavioral control on students' intention to get professional accountant certifications

Hidayat (2010) defined perceived behavioral control as an individual's perception of his/her ability to do a behavior with two aspects being considered: controllability and self-efficacy. Sumaryono (2016) indicated a positive and significant relationship between perceived behavioral control on CA and students' intention to get CA certification. Meanwhile, Solikhah (2014) discovered that perceived behavioral control influences the intention to work as CPA. Therefore, the hypothesis was formulated as follow:

H3. Perceived behavioral control on professional accountant certifications has a positive influence on students' intention to get the certifications.

2.3.4 The influence of comprehension of professional accountant certifications on students' intention to get professional accountant certifications

Arikunto (2009) defined comprehension as the way of how an individual defends, differentiates, explains, expands, concludes, gives examples, rewrites, and estimates something. Comprehension enables students to differentiate, explain, infer, and expand the information on professional accountant certifications.

Information on ACCA, CA, and CPA is required to raise accounting students' intention to get the certifications. The information includes the procedure to get the 
certifications, Regulation of the Minister of Finance of the Republic of Indonesia Number 25/PMK.01/2014 on State-Registered Accountants, and Law of the Republic of Indonesia Number 5 the Year 2011 on the regulation to be a CPA for Indonesian citizens and foreigners. Sumaryono (2016) discovered that there is no positive and significant relationship between students' comprehension on CA and their intention to get the certification. Thus, the hypothesis was formulated as follow:

H4. Comprehension on professional accountant certifications has a positive influence on students' intention to get the certifications.

\section{Research Method}

\subsection{Population and Samples}

The population was undergraduate students from the accounting program of the faculty of economics in Universitas Islam Indonesia, Universitas Gajah Mada, and STIE YKPN. The samples were selected using purposive sampling method, involving seniors from batch 2013 who were about to graduate soon.

\subsection{Data Collection Method}

The primary data of this study were collected using a questionnaire which was distributed online via https://goo.gl/forms/qD7S9OW4qJMUtvGF3.

\subsection{Operational Definition of the Variables}

The dependent variable (Y) of this study was students' intention to get ACCA, CA and CPA certifications, which was measured using a modified Likert scale with 4 responses (Strongly Agree, Agree, Disagree, and Strongly Disagree) reflected in four questions. The independent variables (X) included attitude, subjective norms, and perceived behavioral control, which were measured using 1-4 Likert scale (Strongly Agree, Agree, Disagree, and Strongly Disagree), and there were 30 questions in total. The independent variable of comprehension was measured using a 1-4 Likert scale with different responses, namely Completely Understand, Understand, Not Understand, Completely Not Understand, and it was reflected in 11 questions. 


\subsection{Data Analysis Methods}

\subsubsection{Descriptive Statistics}

Frequency analysis was applied in this study. According to Wahyono (2002), frequency analysis is an analysis comprising the big picture of data frequency used to summarize relatively large data. The result of the descriptive analysis is minimum and maximum frequency, mean, and standard deviation.

\subsubsection{Data Quality Test}

According to Sujarweni (2016), the validity test is conducted to indicate the appropriateness of each question item in defining a variable. Validity test is better conducted on each question item by comparing the result of $r$ count with $r$ table, in which $\mathrm{df}=\mathrm{n}-2$ with $5 \%$ of significance level. If $\mathrm{r}$ table $<\mathrm{r}$ count, the question item is valid.

Reliability is a measure of stability and consistency of respondents in answering each question item which represents a variable arranged in a questionnaire. If the score of Cronbach's Alpha > 0.70, a variable is reliable (Ghozali, 2006).

\subsubsection{Data Analysis Method}

double linear regression model applied in this study was:

$$
Y=\alpha+\beta_{1} X_{1}+\beta_{2} X_{2}+\beta_{3} X_{3}+\varepsilon
$$

$$
\begin{aligned}
& \mathrm{Y}=\text { Students' intention to get CA, ACCA and CPA certifications } \\
& \alpha=\text { Constant } \\
& \mathrm{X}_{1}=\text { Attitude } \\
& \mathrm{X}_{2}=\text { Subjective norms } \\
& \mathrm{X}_{3}=\text { Perceived behavioral control } \\
& \mathrm{X}_{4}=\text { Comprehension } \\
& \beta=\text { Regression coefficient } \\
& \varepsilon=\text { Error }
\end{aligned}
$$




\section{Results and Discussion}

\subsection{Data Collection Result}

The questionnaire was distributed to 136 participants. 109 participants answered it thoroughly while 27 of them did not, making the data unable to be processed.

\subsection{Descriptive Statistics}

Table 1

\begin{tabular}{|l|r|r|r|r|r|}
\hline Variable & \multicolumn{1}{|c|}{$\mathrm{n}$} & \multicolumn{1}{c|}{ Minimum } & Maximum & \multicolumn{1}{c|}{ Mean } & \multicolumn{1}{c|}{ Std. Deviation } \\
\hline Intention & 109 & 2.0 & 4.0 & 2.965 & .5394 \\
Attitude & 109 & 2.1 & 4.0 & 3.139 & .3724 \\
Subjective norms & 109 & 1.5 & 4.0 & 2.617 & .5605 \\
Perceived & 109 & 1.7 & 4.0 & 2.964 & .5199 \\
behavioral control & & & & & .3587 \\
Comprehension & 109 & 1.9 & 4.0 & 3.031 & \\
Valid n (listwise) & 109 & & & & \\
\hline
\end{tabular}

Source: Primary data, processed (2017).

The minimum-maximum score range for intention is 2.0-4.0. The mean for this variable is 2.965, and its standard deviation is 0.5394, showing that the measure of dispersion for intention is 0.5394 from 109 respondents being examined. The minimummaximum score range for attitude is 2.1-4.0. The mean for this variable is 3.139, and its standard deviation is 0.3724 , showing that the measure of dispersion for this variable is 0.3724 from 109 respondents being examined.

The minimum-maximum score range for subjective norms is 1.5-4.0. The mean for this variable is 2.617 , and its standard deviation is 0.5605 , showing that the measure of dispersion for this variable is 0.5605 from 109 respondents being examined. The minimum-maximum score range for perceptive behavioral control is 1.7-4.0. The mean for this variable is 2.964 , and its standard deviation is 0.5199 , showing that the measure of dispersion for this variable is 0.5199 from 109 respondents being examined.

The minimum-maximum score range for comprehension is 1.9-4.0. The mean for this variable is 3.031 , and its standard deviation is 0.3587 , showing that the measure of dispersion for this variable is 0.3587 from 109 respondents being examined. 


\subsection{Instrument Assessment Result}

According to Sujarweni (2016), the validity test is conducted to indicate the appropriateness of each question item in defining a variable. The result of the validity test for all variables shows that $\mathrm{r}$ count $>\mathrm{r}$ table $(0,1584)$. It means that the questionnaire is valid. Reliability is a measure of stability and consistency of respondents in answering each question item which represents a variable arranged in a questionnaire. The result of the reliability test shows that each variable's Cronbach's Alpha $>0.70$, indicating that the questionnaire in this study is reliable.

\subsection{Double Regression Analysis Result}

Table 2

\begin{tabular}{|c|c|c|c|c|c|}
\hline \multirow[b]{2}{*}{ Model } & \multicolumn{2}{|c|}{$\begin{array}{l}\text { Unstandardized } \\
\text { Coefficients }\end{array}$} & \multirow{2}{*}{$\begin{array}{l}\text { Standardize } \\
\mathrm{d} \\
\text { Coefficients } \\
\text { Beta }\end{array}$} & \multirow[b]{2}{*}{$\mathrm{T}$} & \multirow[b]{2}{*}{ Sig. } \\
\hline & B & $\begin{array}{l}\text { Std. } \\
\text { Error }\end{array}$ & & & \\
\hline (Constant) & -1.128 & 1.611 & & -.700 & .485 \\
\hline $\mathrm{X} 1$ & .155 & .027 & .486 & 5.779 & .000 \\
\hline $\mathrm{X} 2$ & .211 & .049 & .327 & 4.323 & .000 \\
\hline $\mathrm{X} 3$ & -.011 & .055 & -.016 & -.202 & .840 \\
\hline $\mathrm{X} 4$ & .031 & .044 & .057 & .708 & .480 \\
\hline
\end{tabular}

a. Dependent Variable: students' intention to get CA, ACCA and CPA certifications

Source: Primary data, processed (2017)

Based on the table above, the regression equation was formulated as follow:

$\mathrm{Y}=-1,128+0,155(\mathrm{X} 1)+0,211(\mathrm{X} 2)-0,011(\mathrm{X} 3)+0,031(\mathrm{X} 4)+\mathrm{e}$

\subsubsection{Hypothesis 1}

H1: The attitude toward professional accountant certifications has a positive influence on students' intention to get the certifications.

This hypothesis was tested using a regression coefficient significance test from the variable of attitude. The variable has a positive coefficient value of 0.155 and sig-t 
0.000 . With sig-t $<0.05$, there is a positive and significant influence of attitude on students' intention to get professional accountant certifications. This result is in line with Sumaryono (2016), who explained that attitude positively and significantly influences students' intention, and Solikhah (2014) and Trikristiani (2014), who discovered that attitude influences students' intention to start a career as public accountants.

\subsubsection{Hypothesis 2}

$\mathrm{H} 2$ : Subjective norms on professional accountant certifications have a positive influence on students' intention to get the certifications.

This hypothesis was tested using a regression coefficient significance test from the variable of subjective norms. The variable has a positive coefficient value of 0.211 and sig-t 0.000 . With sig-t $<0.05$, there is a positive and significant influence from this variable on students' intention to get professional accountant certifications.

This is in line with the previous studies conducted by Sumaryono (2016), Wardani (2016), Solikhah (2014), and Trikristiani (2014), indicating that subjective norms influence students' intention to get professional accountant certifications.

\subsubsection{Hypothesis 3}

H3: Perceived behavioral control on professional accountant certifications has a positive influence on students' intention to get the certifications.

This hypothesis was tested using regression coefficient significance test from the variable of perceived behavioral control. The variable has a positive coefficient value of -0.011 and sig-t 0.840 . With sig-t $>0.05$, there is no influence from this variable on students' intention to get professional accountant certifications. Therefore, this hypothesis was rejected.

This result shows that perceived behavioral control has a negative and insignificant influence on students' intention to get professional accountant certifications, and this is in line with the study conducted by Wardani (2016) on students' intention to get Chartered Accountant certification. Meanwhile, this result is different from what 
Sumaryono (2016), Solikhah (2014), and Trikristiani (2014) discovered, which is the positive relationship between perceived behavioral control and students' intention to get professional accountant certifications. This hypothesis was rejected presumably because students had the perception that they had no skills, resources, and opportunities to get the certifications, and it could decrease their intention to get certified.

\subsubsection{Hypothesis 4}

$\mathrm{H} 4$ : Comprehension on professional accountant certifications has a positive influence on students' intention to get the certifications.

This hypothesis was tested using a regression coefficient significance test from the variable of comprehension. The variable has a positive coefficient value of 0.031 and sig-t 0.480 . With sig-t $>0.05$, there is no influence from this variable on students' intention to get professional accountant certifications. Therefore, this hypothesis was rejected.

This result is in line with Sumaryono (2016) and Trikristiani (2014), who discovered that the level of comprehension does not influence students' intention to get certified. Comprehension investigated in this study comprises CA requirements for foreigners, requirements for professional accountant certification tests, experiences in accounting, job opportunities provided by ACCA, titles awarded after having the tests, and public accountant license.

This result shows that comprehension has no significant influence on students' intention to get professional accountant certifications. This may be due to the lack of students' comprehension on the certifications, Regulation of the Minister of Finance of the Republic of Indonesia Number 25/PMK.01/2014 on State-Registered Accountants Chapter III Article 4 on professional accountant certification tests and Chapter VI Article 7 on foreigners, and Law of the Republic of Indonesia Number 5 Year 2011 Chapter III Article 6 on the Licensing of Public Accountants. Therefore, related parties such as study programs, higher education, and the government should conduct more socialization on professional accountant certifications as well as the state regulations to 
increase students intention to get certified, leading to the increasing number of professional accountants in Indonesia.

\section{Limitation and Conclusion, and Implications}

There were several limiting factors in this study: 1). This study used a questionnaire, and thus the collected data only represent students' opinions on their intention to get professional accountant certifications. 2_. The participants were limited to accounting students from UII, UGM, and STIE YKPN.

Based on the results of this study, it can be inferred that: 1). Attitude toward professional accountant certifications has a positive and significant influence on students' intention to get the certifications; 2). Subjective norms on professional accountant certifications have a positive and significant influence on students' intention to get the certifications; 3). Perceived behavioral control has a negative and insignificant influence on students' intention to get professional accountant certifications. This is presumably because students had the perception that they had no skills, resources, and opportunities to get the certifications; and \$). Comprehension on professional accountant certifications has no positive and significant influence on students' intention to get the certifications.

\section{References}

Arikunto, S. 2009. Dasar-Dasar Evaluasi Pendidikan (edisi revisi). Jakarta: Bumi Aksara.

Ajzen, I. 1991. The Theory of Planned Behavior, Organizational Behavior, and Human Decision Process, 50:179-211.

BPS. 2010. Penduduk Indonesia Menurut Kelompok Umur dan Jenis Kelamin. Retrieved December 20, 2016 at 10:00 WIB from http:// sp2010.bps.go.id.

C, Anton. 2014. Indonesia kekurangan akuntan profesional. Sindo News, p. 1. Retrieved October 21, 2016, at 10:00 WIB from http://ekbis.sindonews.com.

Fishbein, M. and Ajzen, I. 1975. Belief, Attitude, Intention, and Behavior: An Introduction to the Theory and Research. London: Addison-Wesley Publishing Company. 
Ghozali, I. 2006. Aplikasi Analisis Multivariate dengan Program SPSS. Semarang: Badan Penerbit Universitas Dipenogoro.

Hidayat, W. 2010. Studi Empiris Theory of Planned Behavior dan Pengaruh Kewajiban Moral Pada Perilaku Ketidakpatuhan Pajak Wajib Pajak Orang Pribadi. Jurnal Akuntansi Keuangan, 12 (2): 82-93.

IAI. 2014. Presentasi Chartered Accountant, jumlah lulusan akuntansi. Retrieved October 21 , 2016 at $10: 20$ WIB from http://www.iaiglobal.or.id/v03/files/file_ca/presentasi_ca/\#/60.

Indarto, L, S., Endah, D, M, S., dan R, A, D, S. 2013. Analisis Pengalaman dan Jenis Profesi Auditor Pada Indentifikasi Organisasi dan Indentifikasi Sosial klien Terhadap Obyektifitas Penilaian Auditor. Simposium Nasional Akuntansi 16. Retrieved October 12, 2016 at 12:00 WIB from file:///C:/Users/USER/Downloads/Simposium_Nasional_Akuntansi_16_Manado_s.pdf.

Arisudana, I. 2009. Intensi Berbagi Pengetahuan ditinjau dari Ekstraversi, Sikap, Norma Subjektif, dan Kontrol Perilaku yang Dipersepsikan. Thesis. Fakultas Psikologi UGM.

Jogiyanto, H. M. 2007. Sistem Informasi Keperilakuan.Yogyakarta: Penerbit Andi.

Jogiyanto, H.M. 2008. Sistem Informasi Keperilakuan. 2 ed. Yogyakarta: Andi.

Regulation of the Minister of Finance. 2014. Regulation of the Minister of Finance of the Republic of Indonesia Number 25/PMK.01/2014 on State-Registered Accountants. Retrieved Oktober 21, 2016 at 13:00 WIB from http://iaiglobal.or.id/v03/image/ca/PMK\%20Akuntan\%202014.pdf.

PPPK. 2016. Akuntan profesional di Indonesia. Retrieved October 21, 2016 at 11:00 WIB from PPPK.kemenkeu.go.id.

Sulistiani, D. 2012. Faktor-Faktor Yang Memengaruhi Niat Mahasiswa Akuntansi Untuk Berkarir Sebagai Akuntan Publik: Aplikasi Theory of Planned Behavior (Studi Empiris pada Mahasiswa Universitas Diponegoro). Undergraduate Thesis. Universitas Diponegoro.

Sumaryono. 2016. Pengujian Pengaruh Theory of Planned Behavior dan Tingkat Pemahaman Mengenai Chartered Accountant Terhadap Niat Mahasiswa Untuk Mengambil Sertifikat Chartered Accountant. Undergraduate Thesis. Universitas Negeri Yogyakarta.

Solikhah, B. 2014. An application of theory of planned behavior towards CPA Career in Indonesia. Procedia - Social and Behavioral Sciences, 164(August), 397-402. Retrieved October 13, 2016, at 12:00 WIB from https://doi.org/10.1016/j.sbspro.2014.11.094.

Sujarweni, V.W. 2016. Kupas Tuntas Penelitian Akuntansi dengan SPSS. Yogyakarta: Pustaka Baru Press. 
The Indonesian Journal of Accounting Research - Sep, Vol. 21 , No.3, 2018

The ASEAN Secretariat. 2015. The ASEAN economic community 2015: progress and key achievements. Retrieved October 13, 2016, at 13:00 WIB from http://www.asean.org/storage/images/2015/November/aec-page/AEC-2015-Progress-andKey-Achievements.pdf.

UU RI. 2011. Undang-Undang Republik Indonesia Nomor 5 tahun 2011 Tentang Akuntan Publik. Retrieved October 24, 2016, at 11:00 WIB from http://www.dpr.go.id/dokjdih/document/uu/UU_2011_5.pdf

Wardani, G. A. S. 2016. Niat untuk mengambil chartered accountant dengan theory of planned behavior. Undergraduate Thesis. Universitas Diponegoro.

Wahyono, T. 2006. 36 Jam Belajar Komputer Analisis Data Statistik dengan SPSS 14. Jakarta: Penerbit PT Elex Media Komputindo.

Trikristiani, F, Y. 2014. Pengujian Theory of Planned Behavior dan Pengaruh Pemahaman terhadap Undang-Undang Nomor 5 Tahun 2011 tentang Akuntan Publik terhadap Intensi Mahasiswa Akuntansi untuk Berkarier Menjadi Akuntan Publik. Undergraduate Thesis. Program Studi Akuntansi Universitas Negeri Yogyakarta. 